\title{
Hyperdense basilar artery sign
}

\section{Karim Mahawish}

Care of the Elderly, Warrington Hospital, Warrington, UK

\section{Correspondence to} Dr Karim Mahawish, k.mahawish@nhs.net

Accepted 27 January 2015
CrossMark

To cite: Mahawish K. BMJ Case Rep Published online: [please include Day Month Year] doi:10.1136/bcr-2015209317

\section{DESCRIPTION}

A 48 -year-old man presented with a 24 h history of neck pain, vomiting, vertigo and impaired gait. On examination, he was found to have left gaze provoked nystagmus and left arm and leg dysmetria with mild weakness, symptoms attributable to cerebellar dysfunction. He underwent an unenhanced CT of the brain, which demonstrated possible thrombus in the basilar artery (figure 1). Aspirin $300 \mathrm{mg}$ once daily was started. The following day, his left-sided symptoms deteriorated and he became dysarthric. He underwent MR of the brain including angiography, which demonstrated a filling defect in the basilar artery consistent with thrombus (figure 2), however, there was no haemorrhagic foci. He was started on intravenous heparin. Within a few days his symptoms resolved and he was discharged on clopidogrel.

Basilar artery thrombosis presents in a heterogeneous manner and carries a mortality of $80-90 \%$ if not promptly treated. ${ }^{1}$ In one case series, BAT presented acutely in one-third of patients studied, whereas it followed a progressive course over several weeks in the remainder. The most commonly presenting symptoms and signs included vertigo (54\% of patients), hemiparesis (50\%), bulbar/pseudobulbar signs (74\%), oculomotor signs $(45 \%)$ and headache $(41 \%) .^{2}$ It may arise as the result of artery-to-artery or cardioembolism, dissection with anterograde propagation of embolus/occlusion of the true lumen, or in-situ thrombosis. Accurate diagnosis of BAT relies on MR or CT angiography, as hyperdense basilar

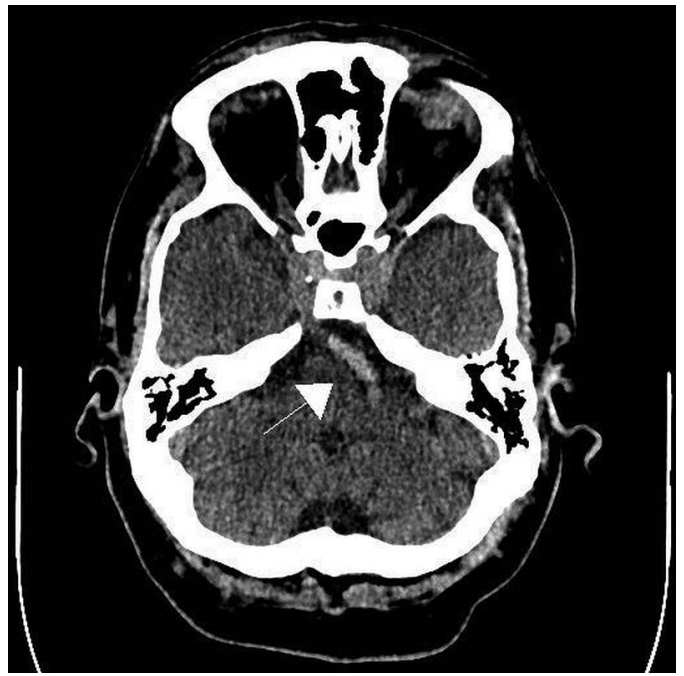

Figure $1 \mathrm{CT}$ of the brain demonstrating hyperdense basilar artery.

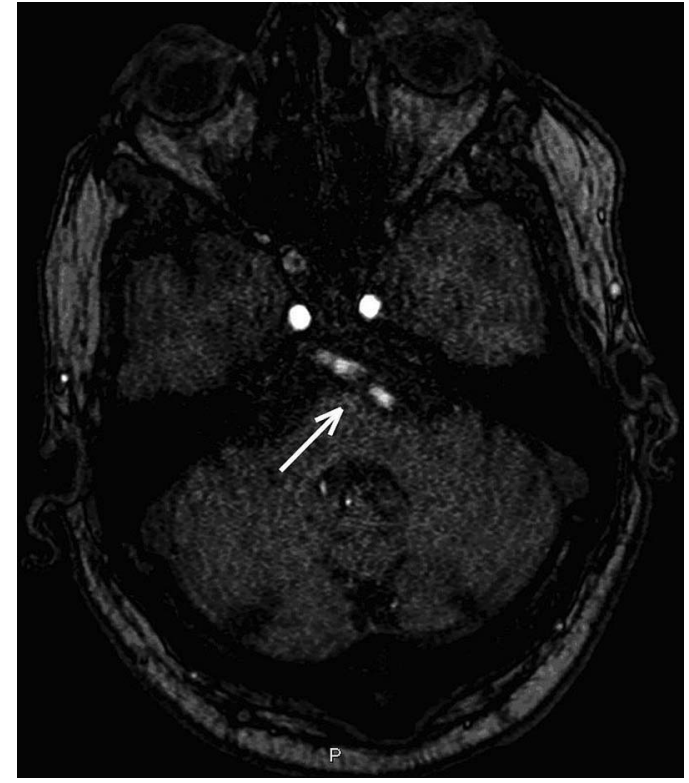

Figure 2 MR time of flight sequence demonstrating thrombus within the basilar artery.

artery on unenhanced CT does not carry sufficient sensitivity or specificity.

\section{Learning points}

- Patients with basilar artery thrombosis may present acutely or with progressive/fluctuating posterior circulation symptoms and signs.

- Basilar artery thrombosis is associated with significant morbidity and mortality.

- Contrast enhanced imaging of the cervicocranial arteries using magnetic resonance or $\mathrm{CT}$ is required for the investigation of this condition.

Competing interests None.

Patient consent Obtained.

Provenance and peer review Not commissioned; externally peer reviewed.

\section{REFERENCES}

1 Hacke W, Zeumer H, Ferbert A, et al. Intra-arterial thrombolytic therapy improves outcome in patients with acute vertebrobasilar occlusive disease. Stroke 1988;19:1216-22.

2 Voetsch B, DeWitt LD, Pessin MS, et al. Basilar artery occlusive disease in the New England Medical Center Posterior Circulation Registry. Arch Neurol 2004;61:496-504. 
Copyright 2015 BMJ Publishing Group. All rights reserved. For permission to reuse any of this content visit http://group.bmj.com/group/rights-licensing/permissions.

BMJ Case Report Fellows may re-use this article for personal use and teaching without any further permission.

Become a Fellow of BMJ Case Reports today and you can:

- Submit as many cases as you like

- Enjoy fast sympathetic peer review and rapid publication of accepted articles

- Access all the published articles

- Re-use any of the published material for personal use and teaching without further permission

For information on Institutional Fellowships contact consortiasales@bmjgroup.com

Visit casereports.bmj.com for more articles like this and to become a Fellow 